\title{
THE INVULNERABLE BODY OF COLOUR
}

\section{The failure and success of a Swedish film diversity initiative}

\author{
MARA LEE GERDÉN
}

$\mathrm{I}^{\mathrm{n}}$ n 2016, the Swedish Film Institute launched the Fusion Programme, the aim of which was to promote diversity in Swedish film production. The announcement of the Fusion Programme emphasised innovation, intersectional analysis, and feminist and anti-racist perspectives on artistic practices. The question of representation is also central, which is reflected in the guidelines for the applicants: 'Applicants must identify himself [sic] as a woman and have experience of [processes of] racialisation in Sweden.' ${ }^{1}$ The application form addressed 'Professional's [sic] creators in the artistic field', stressing an overall artistic expertise and excellence, combined with challenging ideas for film. As a writer and a novelist, I have relentlessly addressed questions of race, gender and power structures, always aiming at producing counter-narratives, but I have also been inspired by the impact of visual forms of art, intrigued and attracted by the directness and force of the film medium. So, I submitted an application that included a synopsis of my idea for a TV series - the main character being a strong woman of colour working as a personal trainer at a gym - and it was accepted. This is how I ended up as one of the participants of the Fusion Programme of 2016.

In this chapter, I examine the affective politics of the Fusion Programme, focusing on tensions between participant motivations and a film policy which, I argue, balanced conflicting frameworks: an outspoken effort to attain goals for gender equality, the desire to implement a perspective on diversity, a notion of quality informing Swedish film policy since the 1960s, and a Swedish self-image expressed as a need to 'implement Swedish values'

In what follows, I discuss the paradox that arises when, paraphrasing Audre Lorde, the master actually summons you to dismantle his house (Lorde, 1996). While launched in the name of advancing diversity in Swedish 
film, there was a clear tension between the quality film rhetoric of the Swedish Film Institute and the participants' insistence on making race play a major role in the respective projects. In my reading, what emerged can be termed 'affective indigestion'. According to a theory of affective labour as metabolisation (Whitney, 2016), the main task of the affective worker is to harbour and 'swallow' the by-products of her work, for instance sadness, disgust or anger, not being allowed to display these kinds of feelings. In my reading, the participants of the Fusion Programme ended up being such affective workers. While emotionally draining for the participants, I will argue that this indigestion made visible the question of affective privilege - which emotions can be articulated, and by whom - and materialised the figure of what I term 'the invulnerable body of colour', i.e. the illusory but common belief that a brown or black body is less sentient/sensitive than a white body. Thereby, it enabled a reconceptualising of pain as a 'racial emotion', which I consider as one of the major outcomes of the Fusion Programme. This reconceptualisation in the context of the arts allows a further exploration of how to avoid the commodification of 'the pain of others' (Sontag, 2003) and instead the turning to a language of vulnerability, thus disclosing a political and creative potential that stresses agency and embodiment.

\section{FUSION AS A DIVERSITY INITIATIVE}

The background of the Fusion Programme was the 2013 reform for film financing in Sweden. ${ }^{2}$ This reform aimed at reaching actual and literal gender equality: to divide funding evenly between men and women. In comparison, the diversity goal expressed in the same plan was spineless. Diversity was described as a 'perspective': 'funding shall be given based on the perspective of diversity. ${ }^{3}$ The same phrasing is found in the bill presented to parliament in 2016. While the 50/50 gender equality mandate of Anna Serner is by now famous all over the film world, putting Sweden on the map as a leading country regarding gender issues, we are definitively lagging behind as far as diversity issues are concerned. A 'perspective' is not binding in any way and entails few obligations, and is thus easily reducible to mere surface, or, in the words of Sara Ahmed, a form of 'institutional polishing' (2017: 102). The problems with diversity initiatives have been closely scrutinised over the years, and the objective of this chapter is not to offer any systematic analysis of them. Instead, I want to focus on one specific aspect of this Swedish initiative: how diversity and quality, in terms of rhetoric, feed into each other.

One of the assumptions of the Fusion Programme was that an increase of minorities in the cultural industry would improve both quality and equality. This assumption may be contested in various ways, but a major objection is 
that 'diversity is also a technology of power, a means of managing the very difference it expresses' (Grey, 2016: 242). As such, there is a great risk that diversity remains a 'difference that doesn't make a difference', as Angela Davis puts it. ${ }^{5}$ In such case, race becomes a commodity to consume, drawing from the notion of 'racial capitalism', which 'then leads to the exploitation of nonwhite racial value' (Leong, 2013: 2198). In Living a Feminist Life, Ahmed pinpoints how diversity work pinions the diversity worker: 'Doing diversity work has taught me that agreeing to something is one of the best ways of stopping something from happening' (Ahmed, 2017: 137). Another problem is that 'diversity' only seems to encompass 'the good stuff', leaving all the difficult issues out. Sara Ahmed argues that 'the fact that diversity is not a scary word is part of the problem: if it is detached from scary issues, such as power and inequality, it is harder for diversity to do anything in its travels' (2012: 66).

As an exclusively positive term, diversity accumulates 'positive affective value' and becomes a 'feel good politics', ready at any time to consume the other (Ahmed, 2012: 67f.). It can thus easily be reduced to a means that allows for immense pleasure and consumption while at the same time creating the illusion of equality. As a consequence, a question arises: what happens to the negative affects that diversity projects might entail? The 'bad feelings', the discomfort, the calling into question, the call outs, the pain that it may cause? Are they simply swept under the carpet? Where and with whom do these negative affective residues end up?

Despite the vagueness of the diversity goal in the film agreement, Baker Karim, a Swedish film director who was appointed a public film commissioner in 2013, set out to make a difference: 'We have a chance to make a Swedish film that is internationally relevant, quality driven and urgent, contributing to the glory yet to come, of Swedish film, Karim says in the press communiqué released at the time of his appointment. ${ }^{6}$ Finding new voices was the means by which to achieve this, and Karim emphasises that 'diversity and gender equality is a quality criterion.' Earlier that year, as a member of Tryck, an organisation for Swedish cultural workers from the black diaspora, Karim initiated the Black List project, a catalogue consisting of black cultural workers aiming at directing attention to black invisibility in Swedish culture. ${ }^{8}$ In the wake of this initiative, he received 10,0oo letters and emails of hate, some of them claiming that he excluded white people (Kulturnytt, 2013a). In 2014, within the frame of the Swedish Film Institute, he continued the diversity work with the launch of 'Black is the new black', a combined screenplay contest and seminar, aiming at highlighting film and creative work that challenge stereotypes of Africa and blackness (Svenska Filminstitutet, 2014). Finally, in November 2015, Karim and the Swedish Film Institute presented 'Beyond the new black', a seminar that focused on the newly invented term 'norm creativity' (Svenska Filminstitutet, 2015). 
Norm creativity was introduced to replace 'norm criticism', by now a well-established conceptual tool in Swedish diversity policies. It has been implemented over the past ten years in order to discern power structures and unpack the categories of normal and desirable, on the one hand, and deviating and undesirable on the other (Bromseth and Darj, 2010; Elmeroth, 2012; Martinsson and Reimers, 2014). It has been a critical tool for analysing normativity in relation to gender, sexuality, functionality and ethnic variation. As a diversity policy tool, norm critical pedagogy and methods have been implemented at Swedish schools, institutions and kindergartens by certified norm critical consultants. In film policy language, the change from 'norm criticism' to 'norm creativity' signalled a shift of focus from the analysis of discourses of power to creative practices and change. ${ }^{9}$ Hence, the 'Beyond the new black' seminar reframed questions of diversity and representation in an empowering context, and it was also the occasion when the Fusion Programme was presented.

The gender equality goal of the Swedish Film Institute had previously been met by suspicion and critique, ${ }^{10}$ but the loudest criticism coincided with the launch of the Fusion Programme in late 2015 (see figure 9.1). In an article in Dagens Nyheter, several persons questioned what they termed 'identity politics' pursued by Anna Serner, the present CEO of the Swedish Film Institute, and public film commissioner Baker Karim. These critics saw Serner and Karim as responsible for the 'identity politics' that is supposedly

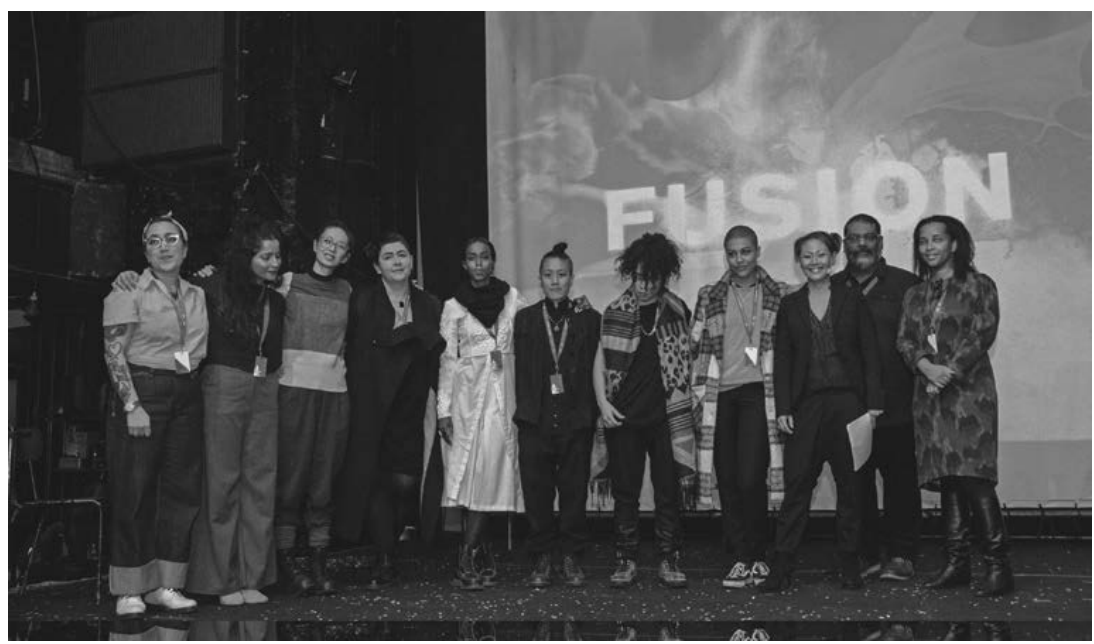

Figure 9.1 Launching the Fusion Programme in January 2016 with participants Aida Chehrehgosha, Saadia Hussain, Mara Lee Gerdén, Farnaz Arbabi, Farah Yusuf, MyNa Do, Nikeisha Andersson, and Saleen Gomani together with jury members Klara Grunning, Baker Karim, and Sara Waldestam. 
'a threat against both economy and artistic quality in Swedish film'. In their view, achieving the policy goals has become more important than the actual films being made (Nordström, 2015).

\section{FUSION AS A QUALITY FILM INITIATIVE}

When launched, Fusion was described as a 'research and development program with financial support, technology and network[ing]' that offered its participants the possibility to develop a film project over one year. Seven projects were chosen. We were artists, directors for stage and film, photographers and one writer (me).

In my project, I wanted to work with a comedy set in a sports environment. My ambition was to go straight to the heart of Swedishness (sports, comedy), but at the same time defying and fighting racial stereotypes (casting an Asian-looking Swedish woman in the leading role, performing Swedishness perfectly). Artist and art pedagogue Saadia Hussain worked on a project about Muslim women and feminism, turning the tables by displaying religious devotion not as subordination but as strength, community and sisterhood. Music video director Nikeisha Andersson worked on a feature film, a genre movie with strong women in the leading roles. Then there was the artist duo Mahoyo, consisting of Farah Yusuf and MyNa Do. They were working on a film project in several parts, documenting the cultural scenes in parts of the world that are often named the global south' The whole Mahoyo 'experience' is about contesting stereotypes and exploring cutting-edge cultural expressions in music and the arts, turning their back on the white gaze. Saleen Gomani worked with a virtual reality project addressing non-normative desire, such as fetishism and BDSM, especially oriented towards rewiring the sexual agency of women of colour. Theatre director Farnaz Arbabi worked on a project addressing mental health among immigrants, and how this phenomenon is made invisible and thus extremely difficult to approach. And lastly, the project of artist Aida Chehrehgosha could be seen as part of an ongoing artistic project of hers approaching the family, this time with a focus on the intra-generational aspects through which histories of pain and love are handed down.

The ambitious aim of developing a film project over one year was to be realised with a series of rapid and professional networking encounters, workshops and seminars. The budget was minimal, entailing less than 300,000 euros for seven film projects, so consequently there was an emphasis on speed and risk, as opposed to slow development and low risk.

When publicly criticised for trying to 'control artistic processes' and pursuing identity politics in the Swedish film industry, Karim stressed over and again how the new creative perspective of the Swedish Film Institute, 
which also made the Fusion Programme possible, had nothing to do with 'regulating' or 'controlling' the film industry. Instead, Karim reassured that 'affirmative action is a means to fight mediocrity. We have to make sure that the mediocre isn't accepted, [just] because they are men' (Nordström, 2015).

The rhetoric of avoiding mediocrity invokes the 1963 film policy plan conceived and initiated by the former head of Swedish Film Institute Harry Schein - which introduced a new concept of artistic quality that ever since has been repeated and thus validated by the film industry (Lantz, 2009; Snickars, 2010: 159). One of Schein's arguments was that quality would enable film to find new international markets (Snickars, 2010: 167). In Schein, 'quality' was constructed as not necessarily satisfying the popular taste, ${ }^{11}$ but rather something that lay 'one step ahead', even defying popularity (Snickars, 2010: 163).

The 1963 film policy plan states that the purpose of the newly founded Swedish Film Institute is to 'support valuable Swedish film production, to support artistic and technological development as well as education and research within the area of film' (Schein, 1970: 235). The definition of quality, and how to assess quality, is defined by:

renewal of the means of expression and formal language of film, the degree of urgency in its message, the intensity or freshness of its perception of reality or its criticism of society, the degree of psychological insight and spiritual level, playful imagination or visionary strength, epic, dramatic or lyrical values, the technical skill displayed by the screenplay, directing, acting and other artistic components in film. (Schein, 1970: 235) ${ }^{12}$

The relevance and impact of these few lines on the Swedish film industry cannot be understated. Today, the public film commissioners still use this definition as a guideline in their evaluation of which projects will or will not receive financial support (Elwin Frenkel, 2010: 236). Also, its relative vagueness makes it easy to adapt to various purposes, including using it as an instrument to preserve the status quo and the existing power structures. ${ }^{13}$

In his rhetoric, Karim comfortably referenced the Schein perspective of quality where exclusion of the mediocre is one of the fundamental aspects. ${ }^{14}$ But, at the same time, he employed the Schein language to implement a new agenda, thus turning the tables. Schein would probably not agree that affirmative action or state interference would enhance quality, as he repeatedly and firmly stated that the arts are inherently undemocratic (Vesterlund, 2013: 57).

This 'new' take on Schein's argument on quality was also found in the 2015 government memorandum 'Framtidens filmpolitik' (which anticipated the final cancellation of the 1963 film agreement) and the subsequent 2015/16 bill 'Mer film till fler - en sammanhållen filmpolitik' presented to the Swedish 
government. In the memorandum, equality and diversity are 'not only an end in [themselves], but the very premise for quality' (Kulturdepartementet, 2015: 4). In the final bill, 'a crucial element for consolidating the quality and relevance of Swedish film in the future is the increase of diversity and equality' (Prop. 2015/16:132: 17). In the memorandum, the ambition to support equality and diversity was however combined with yet another perspective displayed later on in the document: 'In our effort to promote Swedish film culture internationally, the Film Institute works actively with implementing Swedish values concerning democracy, freedom of speech, equality and representation' (Kulturdepartementet, 2015: 16). Implicitly, Swedish values were presented as potentially enhancing human rights such as freedom of speech, but also democratic rights, gender equality and anti-racism, of which it is incumbent upon the Swedish culture to implement internationally.

The instances where the quality concept of Harry Schein coincides with the language used in the Fusion Programme are too many to overlook. The expression 'the intensity or freshness of its perception of reality' from the Schein plan is found more or less to the letter in the application form for Fusion: 'Applications are evaluated by the jury based on ... the freshness of the candidate's perception of reality, or ... the creative intensity of the candidate's creative process. ${ }^{15}$ After the applicants were chosen, the motivations of the jury were publicly displayed in a language that continued to echo Scheinian rhetoric: expressions such as 'technical skill', 'renewal' of the art form and 'criticism of the society' reiterate the language of the 1963 policy plan. Of the remaining expressions, some coincide with the goals of the new bill from 2013, and most importantly the one aiming at full gender equality and the ambition to implement 'Swedish values' around the world. Thus, expressions like 'feminist voice' as well as 'democracy' and 'freedom of speech' were found in the motivations. The remaining words expressed either professional expertise or qualities that could be interpreted as challenging existing norms: 'norm-creative', 'rebellious', 'challenging artistic expressions' and 'norms', and 'stereotypes'. The last category of words clearly bore the mark of the diversity initiatives introduced by Baker Karim, testifying to a diversity-oriented 'Karim-paradigm' of the Swedish Film Institute.

The jury motivations hence echoed a range of historically traceable attempts at reforming the Swedish film industry. So, even if Fusion was, on the surface, presented as a wholly new feminist and anti-racist (even separatist) venture accepting only women of colour working in the arts as members, its construction and very premise were, at a closer look, built on the foundation of the norms, values and powers that it was supposed to challenge.

Summarising the aesthetic and political outset of the Fusion Programme, the main and defining premises that emerge were the following: (1) a fiftyyear-old quality concept forged by a 'Social Democratic cultural aristocrat' 
(Snickars, 2010: 164, 172); (2) a newly adopted effort to attain gender equality goals and also bring about a 'perspective' of diversity, that was in fact a reformulation of an old quality concept; (3) a certain Swedish selfimage expressed by a desire to 'implement Swedish values'; and (4) seven film projects that, while at first sight fed into the 'diversity/quality project' of SFI, soon turned out to be not the least interested in supporting a vague or generalised 'quality concept' or a diversity initiative in which real and lived difference runs the risk of being domesticised and reframed as manageable difference - i.e. as commodities.

We were a group of eight women of colour. Our 'diversity' was supposed to feed into the quality notion of SFI, strengthening and validating its legitimacy. Instead, the collective force of the projects actually seemed to question the very foundations on which this quality concept was forged. From our very first meeting onwards, there was a feeling of something opening up, something being destabilised. My initial thought was that we could actually change something for real. It sounds like an impossible feat but, at the same time, if ever the master's house were to be dismantled, why not now?

\section{REPRESENTING PAIN}

Our introductory meeting took place during the Gothenburg Film Festival in January 2016. It was the first time I had found myself in a room with only women of colour, including the two project managers Sara Waldestam and Klara Grunning. During this first seminar, all of us presented our respective projects. One of the most important discussions that arose, and that, in my view, became key throughout the Fusion year, was the question of pain. First of all, pain emerged as a central - if not always explicit - theme in the majority of the participants' projects, but also as a recurring emotion that circulated in the room as a consequence of the affective clash between the institutional desire to produce diversity and the participants' refusal to submit to that desire.

I presented my project as a counter-narrative insisting on avoiding depictions of the pain of others, explicitly turning away from the image of the brown woman as constantly victimised and in need of rescue. My decision to situate my main character at the heart of the health industry as a personal trainer at a gym was a way to wire her directly into a certain kind of health-conscious, middle-class Western lifestyle, thus fighting racial stereotypes and instead stressing the potential for identification by downplaying differences. It was also a way for me to overtly avoid the very common hyper-feminisation and sexualisation of Asian women (Cho, 1997: 178-211; Chou, 2012; Parrenas, 2007). As a personal trainer, your body is indeed 
central, but not necessarily the object for (sexual) consumption, and instead a physical authority with the power to define and sculpt other bodies. I wanted to challenge the depiction of women of colour as the permanent victims, tired of representations and images that perpetuate the violence against us and normalise our pain, turning our wounds into a consumer spectacle. The contemporary representations of brown and black women as either hyper-sexualised or victims of trafficking, rape and abuse (or forever smiling contently), domestics, maids and nannies, invariably subjugated under either God or man, ${ }^{16}$ are variations of stereotypes of the subjugated brown and black woman handed down for centuries in Western culture. These images are closely connected to the civilising missions of colonial rule, as any white saviour or rescue narrative requires the construction of a brown or black victim to be saved. Historian and gender studies scholar Anne McClintock explains: 'North African, Middle Eastern and Asian women were, all too often, trammeled by the iconography of the veil, while African women were subjected to the civilising mission of cotton and soap. Arab women were to be "civilised" by being undressed (unveiled), while sub-Saharan women were to be "civilised" by being dressed' (McClintock, 1995: 31). In the Fusion Programme, some of us intended to challenge these stereotypes by creating new images: feminist Muslim women, Asian nonconforming femininity, and women of colour forging solidarity across borders, with an emphasis on agency, sisterhood and empowerment.

From the perspective of pain, the other tendency amongst the participants was strikingly different, in fact seemingly almost the opposite - a redirected attention to our wounds, as in the project of theatre director Farnaz Arbabi. The premise of this project was that the pain of others was rarely recognised at all, leading to escalating mental ill health among immigrants. Her project wanted to explore and make visible this pain and the voices of those who are rarely heard.

At first sight, our respective views seemed incompatible, even contradictory, resulting in a 'tie' which could be articulated as the impossible questions: do we need to pay more or less attention to our wounds? Do we need to emphasise or downplay affects such as pain? Representing the pain of others can sometimes become an empowering tool; a way to acknowledge and recognise wounds that for decades have been silenced. But the pain of others can also be used as visual pleasure, a consumer spectacle that risks perpetuating the wounds, turning these images into permanent features. My point, though, is that these views are not incompatible at all, but complementary. How? How can the need to avoid depictions of 'the pain of others' coexist with the need to stress 'the pain of others'?

The need to stress our wounds is grounded in history, but also in contemporary social reality. An interesting experimental study raises the question 
of whether black people are believed to feel less pain than white people (Trawalter et al., 2012). In a series of experiments, a team of psychology scholars wanted to illuminate questions of racial bias in the perception of others' pain. The participants consisted of psychology students (who were given course credit for their participation), nurses and nursing students (who were given gift certificates for their participation) and people recruited on an online marketplace called Mechanical Turk (who were paid a small symbolic sum for their participation). Except from in experiment $2-$ which used all black participants - the vast majority of the participants were white. The results of the study indicated that the participants responded more intensely when watching white people in pain than they did when watching black people in pain. One of the conclusions of the researchers was that racial bias could not explain the participants' lack of empathy with black bodies, but rather 'that people assume that, relative to Whites, Blacks feel less pain because they have faced more hardship. So, the researchers conclude, even if it is not racial bias per se that instigates the lack of empathy, the sheer underestimating of black bodies' pain will have 'potentially disastrous outcomes' (Trawalter et al., 2012).

Even though the Fusion Programme took place in Sweden and our racial reality differs from the American experience, '[n] umerous Swedish studies have reported that mental ill health is more common among immigrants than among native-born', according to social scientist Petter Tinghög, implicating that 'immigrants' mental health can be regarded as one of the most urgent health issues in Sweden today' (2009: 1). In addition, statistics show that immigrant women are overrepresented in suicide rates (de Noli, 2014), and that among transnational adoptees suicide attempt rates are as much as 3.6 times higher when compared to the overall population (Hjern et al., 2002: 443), and as much as 4.7 among male adoptees from South Korea. And just as in the experiments above where people reacted less to pain inflicted on black people, the attempts at explaining these numbers mostly leave out race as a factor. For instance, the researchers behind the study on transnational adoptees and suicide comment on the high suicide rates in a newspaper article, suggesting that they are grounded in the separation that took place in the toddler's earlier years', referring to 'attachment issues'. This explanation erases the following twenty or so years of social reality in the toddler's life, as if these years had nothing to do with the high suicide rates and the risk of everyday racism was wholly insignificant (Letmark, 2003). ${ }^{17}$

These statistics and the findings of the American experimental study indicate that people of colour endure an increase in lived pain but at the same time a reduction of recognised pain, which in turn might explain the profuse occurrences of visual depictions of people of colour in pain. In order to evoke empathy for the black or brown body in pain, the violence 
must increase, it seems, as the viewer basically requires more blood to spark an emotional response (while, at the same time, the excessive violence may always be rationalised by referring to the statistics and thus concealing the underlying mechanisms of a lack of empathy). This suggestion partly coheres with Lauren Berlant's observation 'that scenes of vulnerability produce a desire to withhold compassionate attachment', and even 'to refuse engagement with the scene or to minimise its effects; to misread it conveniently' (2004: 8). And maybe, Berlant suggests, compassion and cruelty are not opposites at all, but instead point towards a relation between compassion and sadism (2004: 8-9).

As for the Fusion Programme, the 'conflicting' aspirations of us participants turned out to be not so conflicting. On the one hand there was an ambition to create counter-narratives fighting the overrepresentation of lived pain, and on the other was the aim to tell the truth about this pain by not under-evaluating it. Some of us aimed at recognising the wound in the first place, saying clearly that we exist and that our wounded histories exist, while some of us felt a need to tend to this wound, trying to heal it. It became clear that these two aims where in fact one, facing and fighting one of the most problematic stereotypes - namely the invulnerable body of colour.

\section{DIVERSITY WORK AND THE INVULNERABLE BODY OF COLOUR}

The affective clashes between the Fusion Programme and the participants were in part a result of our not embracing the idea that 'the promise of diversity $i s$ the promise of happiness', as Ahmed puts it (2012: 165). Instead, we insisted not only on histories of pain, but also that pain is an actual, present and heightened risk in the lives of people of colour. In other words, we refused the 'feel good', the 'overing', of racism, which is the inherent logic of the diversity initiative (2012: 179), and especially we rejected the figure of 'the invulnerable body of colour'.

The paradox that played out through the whole Fusion Programme consisted of the tension between our respective projects that addressed and elaborated aspects of pain and emotional labour (but also creativity and agency) in relation to people of colour, and on the other hand the figure of 'the invulnerable body of colour'. We participants wanted to explore counter-narratives in depth but at the same time the construction of us, and so the participants, as 'invulnerable bodies of colour', informed the whole framing of the programme. The paradox in being discursively situated as 'invulnerable bodies of colour' yet 'chosen' to fight this very same figure became a central issue during the Fusion Programme. 
At the beginning of the year we were asked to make suggestions for guests who were professionals in the creative fields. We made our suggestions, being mostly people of colour working in film or the arts. However, none of the guests we suggested were invited. Instead, the project managers invited guests of their choice. Out of these, none was a person of colour. All of them were extremely competent but our suggestions were completely overlooked, leaving us with the impression that our voices did not count and that the whole procedure of asking us to make suggestions was only a formality. The reason why the project managers did not meet our wishes cannot be explained by lack of funding (as they could obviously fund other guests), access (as they could obviously find other guests) or time. Instead, one possible explanation could be found in the implicit institutional requirements. As the Film Institute and the Fusion Programme itself were saturated by the legacy of the quality guidelines forged by Harry Schein, everything that we tried to articulate that did not fit into them became illegible, and as such not noticed or overlooked.

Our encounters with the invited guests were at best interesting, and at worst disastrous. One of the guests, an accomplished documentary filmmaker, was working on an exceedingly interesting project involving Roma children. The encounter started out well - she discussed ethics, power structures, and checked every box that implied that she was aware of structural inequalities based on race. She was also an avid listener as well as an enthusiastic speaker. But suddenly, out of nowhere, she said the n-word, and not only once but three times, like she had suddenly lost her mind. It took only a few moments for her to recover her composure, realising what she had done and apologising, but the harm was already done. The room had changed. She was so obviously the only white woman in a room full of women of colour.

Thinking about it afterwards, how the most hurtful racist slur suddenly materialised amidst us, served as a reminder of how its emergence in fact cannot be described as coming 'out of nowhere' or as a sudden manifestation, but is to be regarded as quite the opposite. Slurs and hate speech are handed down and repeated as a part of language, and according to Judith Butler acquire their performative force through the acts of iteration and citation, a 'long string of injurious interpellations' that came before (1997: 49). Though elsewhere questioned in terms of responsibility and legal culpability (Mills, 2003: 253-72), Butler's assertion that the speaking subject is the consequence of that very citation' (1997: 50) may shed some light over the invited guest's excuse that she 'did not mean any harm. This utterance displays the difficult distinctions between intention and effect, and also highlights questions of subjective responsibility. The utterance 'I did not mean any harm' performs as an excuse and thus as a performative utterance - it does 
something, namely it tries to undo the previous performative, the slur. But the swift attempt to undo, in this situation, is exactly where the harm lies. A person who does not mean any harm is actually saying 'I did not think this would cause you any harm'. Uttering the worst racist slur that exists thinking that it would not cause any harm to a room filled with black and brown women does not necessarily imply bad intentions, but it does imply racial bias. It implies the perception of us as invulnerable, conjuring up the figure of 'the invulnerable body of colour'.

Even though the other guests did not quite evoke 'the invulnerable body of colour' to that same extent, many of the encounters amounted to very little because the guests refused to meet us where it really mattered for us. For instance, a senior film advisor was brought in to comment on our work, but by leaving out race from his language entirely he had absolutely no tools to assess what we were doing or aiming at. As guests quite literally consecrated their time to persuade us that they were not racists, we ended up with their emotional residues.

\section{AFFECTIVE INDIGESTION/INDIGESTIBLE EMOTIONS}

The emotions evoked by the Fusion Programme recall bell hooks's description of writing a film review:

That will ... to write, to put other things aside to write, to sit at my computer and key in the Beasts of the Southern Wild piece while I am sitting there crying because I just can't take another image of an abused black child being represented as entertaining, and I am sitting there and I am writing, but I am also hurting, I'm hurting because we can't get past the construction of black children as little mini-adults whose innocence we don't have to protect, who we can consider cute if they're being slapped around by an alcoholic father. (The New School, 2013)

There is something very odd in this description. Usually, writing a film review is not associated with profound feelings, and it is not seen as typically laborious. But in hooks's description the emotional investment is huge, and the labour she puts into it enormous. Crying at her keyboard, hurting, her emotional labour seems immeasurable (Hochchild, 1983). And for what? Not a seven-volume novel, not her collected works, but a review of a film that she, on top of everything, hates.

Importantly, it is not just pain or the appalling depictions of black subjects that make bell hooks cry. In my interpretation, the tears are also legible as an expression of unnoticed emotional labour, having to incorporate indigestible emotional residues. Discussing sociologist Encarnación 
Gutiérrez-Rodríguez's research on the affective dimension of the domestic work performed by racialised migrant women in European homes, philosopher Shiloh Whitney uncovers a language of indigestion (GutiérrezRodríguez, 2010: 128; Whitney, 2016). Whitney suggests that understanding the threat of exploitation involved in affective labour 'requires understanding the metabolisation of their by-products' (2016: 285). This affective metabolisation includes absorbing unwanted affects in the environment, for instance if the employer denigrates or insults the worker. 'Just as it becomes part of Elena's job to choke back her anger and Karin's to soak up anxiety, it is part of Carmen's job to swallow her pride' (2016: 286). Their employers use them as containers for affective dumping, whereas the workers themselves are not allowed to express any emotions: 'It is their job to swallow these feelings: to absorb them into their own depths of feeling and contain them there, without allowing them to surface in gesture or posture' (2016: 286). Whitney suggests that this sort of labour 'also produces ... racialisation and gendering. It is women of color who are expected to do this sort of work, and what it means to be a woman of color is being constructed in this practice' (2016: 287). In other words, the affective economy of indigestion affects not only racialised domestic workers, but all women of colour: 'Certain types of bodies are marked for this sort of use, leaving them with the after-hours "dirty work" of metabolising these unwanted affects and with the inevitable affective indigestion from the unexpressed by-products' (2016:287).

As another example of both a language of affective work and that of metabolisation, Whitney invokes Audre Lorde's text 'Eye to eye: Black women, hatred, and anger'. In this text, Lorde describes how: 'As children we absorbed that hatred, passed it through ourselves' (Lorde, 1996: 146). Despite everything, however, hatred in Lorde is perceived not only as an indigestive by-product but as fuel, because from hatred anger may emerge, and anger is fuel, a negative passion (1996: 154).

For me, the notions of affective metabolisation and indigestible affects adequately and accurately describe what the Fusion Programme made visible and evoked among the participants. The emotional labour that took place (from my part, at least, but I think from almost all of us) in the interaction with the guests included downplaying ignorance concerning racial matters, overlooking the more-or-less constant underrating of our artistic expertise, smoothing out misunderstandings that involved race, excusing or pretending not to notice ignorant remarks, 'saving' embarrassing situations or remarks, feeling nervous about them and possible racist remarks, reassuring ourselves that we were not hurting their feelings, and lastly, of course, trying to process the indigestible slur that the filmmaker had left on the table, trying not to make her feel too uncomfortable and saving the situation again. On an emotional level, we were constructed as the invulnerable 
and the guest as the vulnerable, and thus he or she inhabited the double privilege of being the one with discursive, social and racial power, but still constructing themselves as the emotionally (and by all means physically, even if this never arose) vulnerable.

In my reading, the film review 'No love in the wild' by bell hooks referred to above also describes affective indigestion (hooks, 2012). The affective indigestion not only means that bell hooks disagrees with the overall positive reception of the film ${ }^{18}$ and its 'crude pornography of violence', but has to do with the film inflicting images on her, and how this leads to an enforced embodiment of unwanted affects. For instance, in the review bell hooks clearly states that the film put images inside of her head that she did not want there, and she refers to this as 'eating', meaning the images' overwhelming power to affect the viewer. She also says that she saw something that others - judging from the great reviews - did not, which means that she is left alone with both the unwanted violent images of the film and the unrecognised affects that these images evoke in her; lingering inside as affective indigestion, impossible to metabolise.

In other words, in the encounter with artistic representations - and perhaps visual representations in particular - the faculties involved for a woman of colour exceed the merely aesthetic. They may imply having to grapple with the fact that a poetics of violence (against our bodies) is assumed as a quality criterion. It may also situate her in a political economy of affects, leaving her with affective waste products that are indigestible.

This affective violence actualises, in Whitney's words, how 'white privilege is an affective privilege' (2016: 290). This is also the reason why I will now turn to the concept of 'racial emotions' in an attempt to investigate how the double situatedness of pain in the Fusion Programme - both as a representational problem and challenge, but also as an affect produced in the room as a consequence of the collision with the institutional desire enabled a retooling of it in its entanglement with creativity.

\section{RACIAL EMOTIONS}

At the first gathering of the Fusion participants in February 2016, when each and every one presented their projects, the turn of artist Aida Chehrehgosha came. Throughout her career, Chehrehgosha has worked with the family trope, as well as with her own biological family. She told us that she would continue working on this theme, digging even deeper into the family history, going further back in time, beyond her own upbringing and childhood.

She became silent for a moment. We, the other participants, listened carefully to this silence. Then she continued talking, telling us that she and her 
two brothers underwent constant abuse growing up. In her home, domestic violence was a standard procedure - her mom hit her and her brothers, and her father hit her mom. But despite this abuse, or because of it, she had to continue digging. She would look for the sources of this abuse, namely the precariousness of her parents and their vulnerability as newly immigrated Iranians - her father, a former fighter pilot, ending up as a blueberry picker in the Swedish woods. She would work with authentic documents: journals and records of their respective histories. At this point, Chehrehgosha burst into tears, and some things were torn apart in the room - things like decorum and restraint. We immediately left the rules of propriety behind, and instead stepped into a space of deeply felt affinity; a sense of creativity that at the same time bordered on immense pain and necessity. I claim that it was at this moment that the Fusion Programme was forged on an affective level. It was then the participants understood that in this room we would never have to take it from the beginning, from the letter A, every time we needed to address questions that were relevant between us, but start at $\mathrm{W}$, at $\mathrm{O}$, or at $\mathrm{C}$ - i.e. from our own specific situatedness. The account of Chehrehgosha immediately brought the group to the burning affective core of the project, and everybody in that room knew that it was a significant moment.

Importantly, it was not the moment of revelation that forged us together. The abuse that Chehrehgosha told us about was not a secret, as she had mentioned it in interviews before. What happened had nothing to do with providing us with a spectacular piece of pain to be consumed. Quite the contrary, what happened was vulnerability, a shared affective intensity that brought us together as a collective. It was a display of precise artistic integrity combined with vulnerability before a very painful task. In the account of Chehrehgosha, at this moment pain came across as a racial emotion.

Law professor Janine Young Kim suggests that there are emotions that are so closely tied to the experience of race that 'they can be said to demonstrate and typify an emotional dimension of the concept of race' (2016:497). Kim argues that race is something that we not only do or think but also feel (439). Emotions are, however, not restricted to a strictly personal realm. As a discursive expression, they can be understood as both political and social. Therefore, it is reasonable to argue that constructions of race are also performed along emotional lines. Kim concludes that if race is partly affectively constructed then we also have to begin to rethink race (497).

In order to demonstrate the emergence and range of racial emotions, Kim turns to W. E. B. Du Bois, Frantz Fanon and Lorde (again). I share her and many other scholars' understanding of these writers as making a powerful case for the profoundness of the emotions of grief, rage, anger, disgust and hatred as intimately connected to the experience of racial subjectivity. In a passage in The Souls of Black Folk, Du Bois recounts the birth of his first 
son - an event that in most circumstances would provide pure joy. But here, the joy is immediately dampened: 'I saw the shadow of the Veil as it passed over my baby' (Du Bois, 2007: 100). The veil, at the same time the incarnation of grief and the metaphor that Du Bois uses for a life lived behind the colour line, turns joy into grief. A similar emotional pattern recurs later in the book when Du Bois describes his child's premature death, and once again displays strongly ambivalent feelings: grief, of course, but also: 'All that day and all that night there sat an awful gladness in my heart', and 'Not dead, not dead, but escaped; not bond, but free' (Du Bois, 2007: 102). Thinking about the racial destiny that awaits his first born, his emotions do not follow the book. At first sight, they may resemble 'mixed emotions': two conflicting emotions harboured in one body. At a closer look, however, they are nothing like mixed emotions because those expressed by Du Bois at the death of his beloved son - both grief and joy - are utterly incomprehensible and ungraspable without a key reference to race. The context of racial segregation is required for the emotions to make sense. This makes them racial emotions.

Another, more contemporary example that displays the devastating force of racial emotions is Ta-Nehisi Coates' Between the World and Me, where he addresses his young son in a narrative about racial America. In a very personal (and painful) reflection on domestic violence, he shows how even the most intimate emotions are soaked with race:

\begin{abstract}
Now I personally understood my father and the old mantra - 'Either I can beat him or the police.' I understood it all - the cable wires, the extension cords, the ritual switch. Black people love their children with a kind of obsession. You are all we have, and you come to us endangered. I think we would like to kill you ourselves before seeing you killed by the streets that America made. That is a philosophy of the disembodied, of a people who control nothing, who can protect nothing, who are made to fear not just the criminals among them but the police who lord over them with all the moral authority of a protection racket. (Coates, 2015: 82)
\end{abstract}

Here, it becomes clear how the intimate sphere always has been and still is highly political. This should not be read as a condoning of child abuse, but as an attempt at illuminating how race affects the most intimate things, and that not even the love between parent and child will stay untainted by racial oppression.

If race, in Ta-Nehisi Coates, can be said to be the reason why love is intercepted with violence, and, in the case of Du Bois, grief with joy, then the case for racial emotions becomes clearer - sometimes, emotions are not graspable without thinking through race, and sometimes they signify something else in a context of race. If race can turn grief into joy and love into violence, even love into death (as, for instance, in Toni Morrison's Beloved), 
it is obviously not a sign of inherent racial difference but the emotional manifestation of a history of non-acknowledged oppression.

The notion of racial emotions may shed light on certain aspects of the deeply felt vulnerability that we, the Fusion participants, felt and were forged together by at our first meeting. As mentioned, the abuse that Chehrehgosha and her siblings endured during their childhood had been brought up before, and especially in relation to the highly acclaimed and prize-winning series of photographs entitled To Mom, Dad and My Two Brothers, where Chehrehgosha staged the death of her parents. In an interview, she has explained how this project was grounded in affects of anger and hate, but also love:

My upbringing consisted of abuse and constant fear ... My anger was so immense, many times I wanted to see my dad dead. My anger towards my mom was just as strong, mostly when she hit me because of her own frustrated situation. I hated them so much. But it was a very complicated anger. I also loved them. (Chehrehgosha, 2011)

Her photographs capture the ambivalent feelings of 'the eternal, strong hate and the connection that we have, despite everything'. Here, the affective impact of 'mixed emotions' dominates. In her new work presented at the Fusion Programme, however, Chehrehgosha seemed to turn her back on hate, instead approaching the affective realm of pain. In my understanding, the pain articulated in her new project was construed as a racial emotion: the violence that was handed down by her parents was not a personal heritage but a racist legacy, a product of a social, structural and racist violence. Recognising this difference also meant acknowledging pain as an intergenerational affect in this context, suturing her and her parents' wound as a mutual experience that had to do with race. At the moment of recognition, a language of vulnerability emerged as a key to issues of pain and violence; there are injuries that extend over time, and we are in this together. As such, pain was constituted as a racial emotion in the moment that we recognise ourselves as vulnerable subjects. It was almost as if her work was adhering to Ahmed's words: 'To speak about racism is to labor over sore points' (Ahmed, 2012: 171). Perceiving pain through vulnerability as a racial emotion was, to me, the most impactful outcome of the Fusion Programme, allowing us all to approach a language of vulnerability both as a collective and as individual artists.

\section{CONCLUSIONS}

The Fusion Programme had many problems: the historically determined context that turned out to be discursively shaped by the 1960 o quality 
concept, the ridiculously low budget, and, most importantly, the paradox of us participants being discursively situated as invulnerable bodies of colour', yet 'chosen' to fight this very same figure. Nevertheless, we were able to approach aspects of racial emotions challenging this figure, both in our respective projects and the way we struggled to inhabit our discursively determined situatedness in the white rooms of Swedish film industry. Each and every one of us of course employed different strategies in the confrontation with the singular events, but, seen from the point of view of a collective effort, the outcome of the Fusion year was both surprising, instructive and creatively productive. While the institutional frame was saturated with tradition and at times constituted an impediment, it also mirrored the predicaments and obstacles that a woman of colour in the arts confronts on a daily basis. At the same time, the programme provided us with a space to disentangle and address these obstacles - a space that would hardly survive outside of a separatist diversity initiative. This space managed to initiate a retooling of the racial emotions of pain into creativity by highlighting the connections between race, creativity and quality. It also showed how the figures of brown and black pain inconsistently but insistently knit together with 'the invulnerable body of colour' in racist discourse. Not as an antonym but as a variation of the figure of the black or brown victim, the invulnerable body of colour' appears as a viable figure depending on how whiteness chooses to fashion itself. In this programme - and probably as a function of the encounter with us as a collective, i.e. we outnumbered them in our encounters - whiteness chose mostly to inhabit vulnerability, which is why the figure of the invulnerable body of colour became so dominant.

In one sense, the Fusion Programme was a failure. From day one, the affective clash between, on the one hand, the institutional desires/ expectations, and on the other the participants' refusal to submit to these very same desires, became an impediment to the intended 'diversity work' that we were supposed to perform. The benevolent intentions of the diversity policy had a contrary effect that, instead, perpetuated certain wounds and pains, and situated us as affective workers having to clean up the emotional mess and indigestive residues of their diversity goal. In another sense, however, it was a success. We participants managed to install a creative environment where fixed and static figures of pain, anger and hatred most blatantly expressed through the figure of the invulnerable body of colour - were constantly negotiated through the language of vulnerability. This language would never again content itself with two binary takes on the representation of 'the pain of others' as either victim or perpetrator. Instead, the most fruitful outcome was discovering how approaching pain as a racial emotion entailed the responsibility to trace the emotion back in time, until its roots of vulnerability could be grasped. 
A last thought: I fully agree with Sara Ahmed, who says that the brick walls encountered in diversity work are material, real obstacles that testify to the materiality of race and gender (2017: 147). She explains how the mere mentioning of the wall will make you come across as a 'wall maker', as if you were the one who put the wall there, making things 'harder' than necessary (141f.). Drawing from the image of the wall, the figure of the invulnerable body of colour turns out to be even more disturbing. This figure implies that we are not even conceived of as wall makers anymore. Instead, we have become the very wall that was blocking us. In this figure, invulnerability confers neither strength nor resistance, and neither empowerment nor agency. The intricate connections between power, vulnerability and privilege are rarely as evident as when the other, for whom these qualities aren't accessible, is constructed as a less sentient being.

\section{NOTES}

1 Swedish Film Institute. Fusion Programme, www.focal.ch/medici-training/ reports/docs/Medici_W6_Module_6_Fusion.pdf.

2 In Sweden, film financing is organised through 'the film agreement', which also includes a policy and agreement on what films should be produced.

$3 \mathrm{Ku}$ 12:004, English translation of the 2013 Film Agreement. www.regeringen.se/ 4.9bb9d/contentassets/cd4178254.cb843f2a3f1b2febb3e52db/2013-ars-filmavtal, p. 2.

4. Prop. 2015/16:132. Mer film till fler-en sammanhållen filmpolitik, www.regeringen. se/49481b/ contentassets/ 7C57da9ffe184d7cbeo0278f929c5f81/15161320o webb.pdf, p. 8.

5 This is one of Davis' recurring slogans, repeated over the years, for instance in Davis (2012) which also includes a full transcript.

6 Quote from the press communiqué of the appointment of Karim as public film commissioner in (Svenska Filminstitutet, 2013). An appointment lasts for three years. Baker Karim took office in November 2013 and departed at the appointed time in 2016.

7 Karim concludes the interview saying that he will try to 'stir Swedish film into mutiny' by taking risks (Kulturnytt, 2013b).

8 The catalogue eventually changed its name to Kulturarbetarkatalogen Push.

9 This term was especially useful for practitioners in education and communication, rather than for scholars. For further information about this term see Vinthagen and Zavalia (2014).

10 This critique has been voiced ever since the film agreement of 2006, aiming at strengthening gender equality, guaranteeing that at least 40 per cent of a film production team supported by the Swedish Film Institute should be gendered as women. See, for instance, Redvall (2006).

11 According to Schein, the quality of TV and radio programmes could not be defined in terms of 'the ability to attract a bigger audience', furthermore 
suggesting that quality only refers to 'valuable and not audience-oriented shows' (Snickars, 2010: 163).

My translation, and henceforth all translations of Swedish sources will be mine unless otherwise indicated.

13 For instance, in the discussions following the new film policy plan of 2006, quality was allegedly at stake. The object of controversy around this plan concerned its aim to strengthen gender equality, guaranteeing that at least 40 per cent of a film's production team supported by the Swedish Film Institute should be gendered as women. As expected, the discussion that followed revolved around the pros and cons of affirmative action, and the opponents voiced more or less the same argument that is standard in any field where steps towards gender equality or diversity goals are taken: quality, not gender (or race), should determine your opportunity, meaning that affirmative action would lower the quality (Redvall, 2006).

14 'I said that the concept of quality, the raison d'être of the film reform, was not non-controversial ... for those who were not gifted enough to make quality film ... the possibilities would be curtailed' (Schein, 1970: 25).

15 Swedish Film Institute Fusion Programme, https://focal.ch/medici-training/ reports/docs/Medici_W6_Module_6_Fusion.pdf.

16 The tradition of portraying Asians as objectified sex victims to be rescued or discarded in popular culture is overpowering, but the appetite for brutality committed against black bodies seems to be unceasing at present. See Top of the Lake and its follow up China Girl, by the same white female director, 12 Years a Slave, Precious, and most recently Detroit and Orange is the New Black. For further reading see Shimizu (2016) and hooks (2015).

17 I should add that in the actual study the researchers do mention 'discrimination and prejudices against children and youths with a non-Swedish appearance' as a possible explanation for why the researchers found similar results between transnational adoptees and immigrant children, but not as a direct explanation for the increased numbers per se. I should also mention that the word 'race' is not mentioned once in the study.

18 This film was nominated for best picture, best actress, best director and best adapted screenplay.

\section{ACKNOWLEDGEMENTS}

The research for this chapter was financed by the Swedish Research Council.

\section{REFERENCES}

Ahmed, S. (2012). On Being Included: Racism and Diversity in Institutional Life. Durham, NC and London: Duke University Press.

Ahmed, S. (2017). Living a Feminist Life. Durham, NC and London: Duke University Press. 
Berlant, L. (2004). 'Introducing compassion (and withholding)', in L. Berlant (ed.), Compassion: The Culture and Politics of an Emotion. New York and London: Routledge, pp. 1-14.

Bromseth, J. and F. Darj (eds) (2010). Normkritisk pedagogik: makt, lärande och strategier för förändring. Uppsala: Centrum för genusvetenskap, Uppsala universitet.

Butler, J. (1997). Excitable Speech: A Politics of the Performative. New York and London: Routledge.

Chehrehgosha, A. (2011). 'till mamma, pappa och mina två bröder 5/3-3/4 2011', http://galleriformat.nu/2011/aida-chehrehgosha-till-mamma-pappa-och-minatva-broder-53-34-2011 (accessed 16 February 2018).

Cho, S. K. (1997). 'Converging stereotypes in racialized sexual harassment: Where the model minority meets Suzie Wong', Journal of Gender, Race and Justice, 177, pp. $178-211$.

Chou, R. S. (2012). Asian American Sexual Politics: The Construction of Race, Gender, and Sexuality. Lanham, MD: Rowman \& Littlefield.

Coates, T.-N. (2015). Between the World and Me. New York: Spiegel and Grau.

Davis, A. (2012). 'Social justice in the public University of California, reflections and strategies teach-in, keynote address \& student discussion', UC Davis (23 February), https://video.ucdavis.edu/media/Angela+Davis+Teach-InA+Angela +Davis+\%26+Student+Panel/o_g1t9aewg (accessed 16 February 2018).

de Noli, M. F. (2014). 'Självmord bland invandrare ökar', Läkartidningen (January), www.lakartidningen.se/Klinik-och-vetenskap/Kommentar/2014/01/Sjalvmordbland-invandrare-okar (accessed 16 February 2018).

Du Bois, W. E. B. (2007 [1903]). 'Of the passing of the first-born', in H. L. Gates Jr. (ed.), The Souls of Black Folk: The Oxford W. E. B. Du Bois. Oxford and New York: Oxford University Press.

Elmeroth, E. (ed.) (2012). Normkritiska perspektiv: i skolans likabehandlingsarbete. Lund: Studentlitteratur.

Elwin Frenkel, C. (2010). 'Harry och jag', in L. Olshammar, P. Snickars and P. Vesterlund (eds), Citizen Schein. Värnamo: Mediehistoriskt arkiv 14, Kungliga biblioteket, pp. 224-37.

Grey, H. (2016). 'Precarious diversity: Representation and demography', in M. Curtin and K, Sanson (eds), Precarious Creativity, Global Media, Local Labor. Oakland: University of California Press, pp. 241-53.

Gutiérrez-Rodríguez, E. (2010). Migration, Domestic Work and Affect: A Decolonial Approach on Value and the Feminisation of Labour. New York: Routledge.

Hjern, A., F. Lindblad and B. Vinnerljung (2002). 'Suicide, psychiatric illness, and social maladjustment in intercountry adoptees in Sweden: A cohort study', The Lancet, 360:9331, pp. 443-8.

Hochschild, A. R. (1983). The Managed Heart: Commercialization of Human Feeling. Berkeley: University of California Press.

hooks, b. (2012). 'No love in the wild', www.newblackmaninexile.net/2012/og/bellhooks-no-love-in-wild.html (accessed 16 February 2018).

hooks, b. (2015). Black Looks: Race and Representation. New York and London: Routledge.

Kim, J. Y. (2016). 'Racial emotions and the feeling of equality', University of Colorado Law Review, 87:2, pp. 438-500. 
Kulturdepartmentet (2015). Framtidens filmpolitik. Kulturdepartementets promemoria. Ds 2015:31. www.regeringen.se/49b742/contentassets/7e111809096 e45bfbo96ed555ce39dc2/ds-2015_31-inl_web-2.pdf (accessed 16 February 2018).

Kulturnytt (2013a). 'Baker Karim fick 10000 hatmejl', Sveriges Radio (12 March), http://sverigesradio.se/ sida/artikel.aspx? programid $=478 \&$ artikel $=5470613$ (accessed 16 February 2018).

Kulturnytt (2013b). 'Baker Karim vill ge svensk film en ny storhetstid', Sveriges Radio (7 October), http://sverigesradio.se/sida/artikel.aspx? programid=478\&ar tikel $=5667195$ (accessed 16 February 2018).

Lantz, J. (2009). 'Kvalitet', FLM (15 March), http://flm.nu/2009/o3/kvalitet-2.

Leong, N. (2013). 'Racial capitalism', Harvard Law Review, 126:8, pp. 2151-226.

Letmark, P. (2003). 'Självmord vanligt bland adopterade', Dagens Nyheter (15 October).

Lorde, A. (1996 [1984]). Sister Outsider: Essays and Speeches by Audre Lorde. Freedom, CA: The Crossing Press.

Martinsson, L. and E. Reimers (eds) (2014). Skola i normer. Malmö: Gleerup.

McClintock, A. (1995). Imperial Leather: Race Gender and Sexuality in the Colonial Contest. New York: Routledge.

Mills, C. (2003). 'Contesting the political: Butler and Foucault on power and resistance', The Journal of Political Philosophy, 11:3, pp. 253-72.

The New School (2013). 'Black female voices: Who is listening - a public dialogue between bell hooks + Melissa Harris-Perry'. The New School (8 November), www.youtube.com/watch?v=5OmgqXao1ng (accessed 16 February 2018).

Nordström, A. (2015). 'Många kritiska röster mot Filminstitutets identitetspolitik', Dagens Nyheter (27 November).

Parrenas, S. (2007). The Hypersexuality of Race, Performing Asian/American Women on Screen and Scene. Durham, NC: Duke University Press.

Redvall, E. (2006). 'Manliga filmare kritiserar kvotering' ['Male directors criticise affirmative action']. Sydsvenskan (27 August).

Schein, H. (1970). I själva verket. Sju års filmpolitik. Stockholm: Norstedts.

Shimizu, C. P. (2016). 'Equal access to exploitation and joy: Women of color and Hollywood stereotype', Quarterly Review of Film and Video, 33:4, pp. 303-21.

Snickars, P. (2010). 'Vad är kvalitet?', in L. Olshammar, P. Snickars and P. Vesterlund (eds), Citizen Schein. Värnamo: Mediehistoriskt arkiv 14, Kungliga biblioteket, pp. $158-73$.

Sontag, S. (2003). Regarding the Pain of Others. New York: Picador.

Svenska Filminstitutet (2013). 'Baker Karim ny långfilmskonsulent' (7 October), www.filminstitutet.se/sv/om-oss/press/pressmeddelanden/2013/baker-karimny-langfilmskonsulent (accessed 16 February 2018).

Svenska Filminstitutet (2014). 'Black is the new black- manustavling-och-seminarium' (17 September), www.filminstitutet.se/sv/om-oss/press/pressmeddelanden/2014/ black-is-the-new-black--manustavling-och-seminarium (accessed 16 February 2018).

Svenska Filminstitutet (2015). 'Beyond the new black' (9 October), www.filminstitutet. se/sv/se-och-samtala-om-film/filmrummet/evenemang/evenemang/beyondthe-new-black (accessed 16 February 2018). 
Svenska Filminstitutet (2016). Riktlinjer för det redaktionella arbetet med digitaliseringen av filmarvet. 2014/rev. 2016. www.filminstitutet.se/globalassets/2.-fakunskap-om-film/digitala-filmarvet/diverse-bilder/riktlinjer-for-det-redaktionellaarbetet-med-digitaliseringen-av-filmarvet.pdf (accessed 30 December 2016).

Tinghög, P. (2009). Migration, Stress and Mental Ill Health: Post-Migration Factors and Experiences in the Swedish Context (diss.). Linköping: Linköping Studies in Arts and Science.

Trawalter, S., K. M. Hoffman and A. Waytz (2012). 'Racial bias in the perceptions of others' pain', Plos One, 7:11 (14 November): e48546. https://doi.org/10.1371/ journal.pone.0048546.

Vesterlund, P. (2013). 'Vägen till filmavtalet - Harry Scheins filmpolitiska aktivitet innan 1963', Nordisk Kulturpolitisk Tidskrift, 16:1, pp. 45-67.

Vinthagen, R. and L. Zavalia (2014). Normkreativ. Stockholm: Premiss.

Whitney, S. (2016). 'Affective indigestion: Lorde, Fanon, and Gutiérrez-Rodríguez on race and affective labor', The Journal of Speculative Philosophy, 30:3, pp. 278-91. 